\title{
3.3 Ga SHRIMP U-Pb zircon age of a felsic metavolcanic rock from the Mundo Novo greenstone belt in the São Francisco craton, Bahia (NE Brazil)
}

\author{
J.J. Peucat $^{\mathrm{a}, *}$, J.F. Mascarenhas ${ }^{\mathrm{b}}$, J.S.F. Barbosa ${ }^{\text {c }}$, S.L. de Souza ${ }^{\mathrm{b}}$, M.M. Marinho ${ }^{\mathrm{b}}$, \\ C.M. Fanning ${ }^{\mathrm{d}}$, C.M.M. Leite \\ ${ }^{\mathrm{a}}$ Géosciences Rennes, UMR CNRS 6118, 35042 Rennes Cedex, France \\ ${ }^{\mathrm{b}}$ CBPM-Companhia Bahiana de Pesquisa Mineral, Quarta Avenida, Numero 460, Centro Administrativo CEP $41750-300$ Salvador, Bahia, Brazil \\ ${ }^{\mathrm{c} C P G G-C e n t r o ~ d e ~ P e s q u i s a ~ e m ~ G e o f i s i c a ~ e ~ G e o l o g i a / C u r s o ~ d e ~ P o s-G r a d u a c ̧ a ̃ o ~ e m ~ G e o l o g i a ~ d a ~ U F B A-U n i v e r s i d a d e ~ F e d e r a l ~ d a ~ B a h i a, ~ B r a s i l . ~}$ \\ Rua Caetano Moura 123, Federação, 40210-350 Salvador, Bahia, Brazil \\ ${ }^{\mathrm{d}}$ Research School of Earth Sciences, ANU, Mills Road, Canberra ACT0200, Australia
}

Received 2 January 2001; accepted 2 January 2002

\begin{abstract}
Felsic metavolcanics associated with supracrustal rocks provide $\mathrm{U}-\mathrm{Pb}$ zircon and $\mathrm{Sm}-\mathrm{Nd} T_{\mathrm{DM}}$ ages of approximately $3.3 \mathrm{Ga}$, which establish an Archean age of the Mundo Novo greenstone belt. A granodioritic gneiss from the Mairi complex, located on the eastern boundary of the Mundo Novo greenstone belt, exhibits a zircon evaporation minimum age of $3.04 \mathrm{Ga}$ and a Nd model age of $3.2 \mathrm{Ga}$. These results constrain the occurrence of at least three major geological units in this area: the Archean Mundo Novo greenstone belt, the Archean Mairi gneisses, and the adjoining Paleoproterozoic $(<2.1 \mathrm{Ga})$ Jacobina sedimentary basin. The Jacobina basin follows the same trend as the Archean structure, extending southward to the Contendas-Mirante belt, in which a similar Archean-Paleoproterozoic association appears. We postulate that during the Paleoproterozoic in the eastern margin of the Gavião block, these Archean greenstone belts constituted a zone of weakness along which a late-stage orogenic sedimentary basin developed. (C) 2002 Elsevier Science Ltd. All rights reserved.
\end{abstract}

Keywords: Zircon age; Metavolcanic rock; Mundo Novo greenstone belt

\section{Introduction}

Archean and Paleoproterozoic supracrustal associations (greenstone belts) are described in the northeastern part of the São Francisco craton (SFC) in Bahia (Fig. 1). The age of such rock types is often difficult to constrain using geochronological methodologies because of (1) the weak fractionation of isotopic systems studied in mafic and ultramafic rocks and (2) the possible resetting of whole-rock systems during metamorphic processes in both mafic and felsic rocks. In this part of the SFC, high-grade events were developed during the Trans-Amazonian orogeny (ca. $2.1 \mathrm{Ga}$ ), which makes it difficult to interpret the wholerock geochronology. Inherited zircons from metasediments of the SFC provide indirect evidence for an early

\footnotetext{
* Corresponding author. Address: Institut de Géologie Campus de Beaulieu, UPR CNRS 4661, Université de Rennes, Ave du Général Leclerc, 35042 Rennes, France. Fax: + 33223235680.

E-mail address: peucat@univ-rennes1.fr (J.J. Peucat).
}

Paleoproterozoic deposition age (2.15-1.95 Ga) of the upper part of the Contendas-Mirante and Jacobina sedimentary belts (Nutman et al., 1994; Mougeot et al., 1995). However, the best way to date such volcano sedimentary complexes more precisely is to use felsic metavolcanic rocks, which are often associated with mafic rocks and generally contain magmatic zircons. This paper provides TIMS ${ }^{207} \mathrm{~Pb} /{ }^{206} \mathrm{~Pb}$ evaporation and SHRIMP U$\mathrm{Pb}$ zircon ages, as well as some $\mathrm{Nd}$ model ages from a metadacite and surrounding rocks of the Mundo Novo greenstone belt, which is geographically associated with the Jacobina supracrustals.

\section{Geological setting}

In Bahia State, the SFC is represented as a juxtaposition of four Archean continental blocks brought together during convergent and collisional processes at approximately 


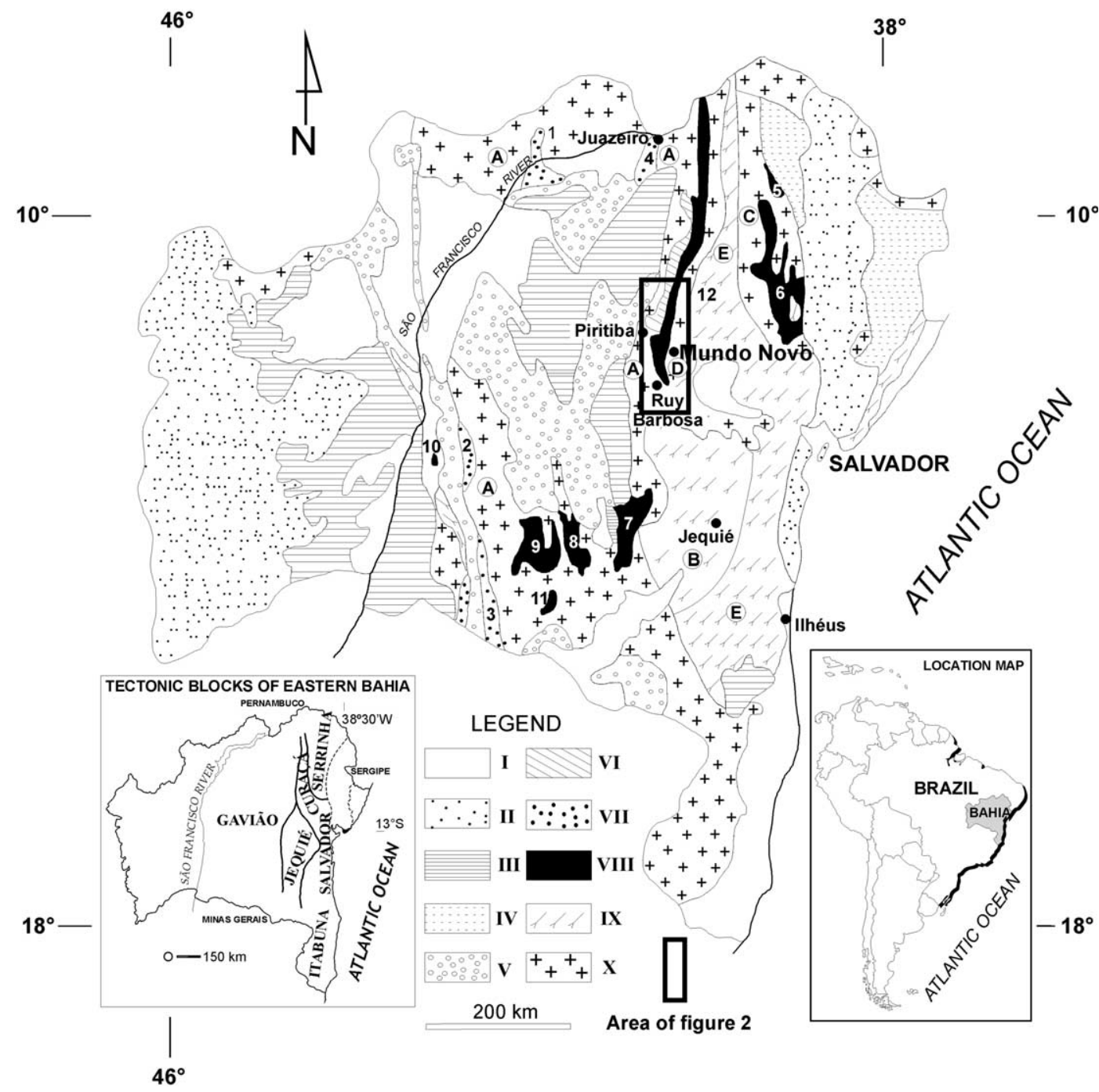

Fig. 1. Geological map of Bahia showing the location of the Mundo Novo greenstone belt (Mascarenhas, 1976). I: Cenozoic cover. II: Mesozoic basins. NeoProterozoic: III: São Francisco supergroup. IV: Sergipano fold belt. Meso-Proterozoic: V: Espinhaço supergroup. Paleoproterozoic to Archean: VI: Jacobina group. VII: Volcano sedimentary sequences (1) Barreiro-Colomi, (2) Boquira, (3) Urandi-Licinio de Almeida, and (4) Rio Salitre. VIII: Greenstone belts (5) Rio Capim, (6) Rio Itapicuru (Serrinha), (7) Contendas-Mirante, (8) Umburanas, (9) Brumado, (10) Riacho de Santana, (11) Guajeru, and (12) Mundo Novo. Archean: IX: Granulitic complex. X: Granitic gneiss terrains (A) Gavião block, (B) Jequié block, (C) Serrinha block, (D) Mairi complex, (E) ItabunaSalvador-Curaçá belt.

2.1 Ga during the Trans-Amazonian orogeny (Barbosa and Sabaté, 2002): the Gavião block, the granulitic Jequié block, the granulitic Itabuna-Salvador-Curaçá belt, and the Serrinha block (Fig. 1).

The Serrinha block in the northeast is considered similar to the Gavião block because of similarities in the rock types observed, even though the oldest Archean terrains (3.4 Ga) found in the Gavião block are not recognized (Sampaio, 1992; Sabaté et al., 1994a,b). The basement is made up of tonalitic, granodioritic, and granitic gneisses yielding $\mathrm{Rb}-$ Sr whole-rock isochron ages of 3.1, 3.0, 2.7, and $2.1 \mathrm{Ga}$ (Mascarenhas and Garcia, 1989; Bastos Leal, 1992); a U$\mathrm{Pb}$ zircon age of $2.9 \mathrm{Ga}$ (upper intercept) is indicated by Gaal et al. (1987). The Rio Itapicuru greenstone belt is Paleoproterozoic. It is composed of tholeiitic basalts with pillow lavas in the lower part, then felsic volcanics with andesites, tuffs and dacites, and clastic sediments at the top (Davison et al., 1988; Silva, 1992). All ages obtained are around $2.2-2.1 \mathrm{Ga}$, with the tholeiitic basalts providing $\mathrm{Sm}-\mathrm{Nd}$ and $\mathrm{Pb}-\mathrm{Pb}$ ages of $2.2 \mathrm{Ga}$ (Silva, 1992). The andesites are dated by $\mathrm{U}-\mathrm{Pb}$ zircon at $2178 \pm 23 \mathrm{Ma}$ (Gaal et al., 1987), in relative agreement with a previous $\mathrm{Rb}-\mathrm{Sr}$ whole-rock isochron age of $2080 \pm 90 \mathrm{Ma}$ (Brito Neves et al., 1980). These ages are also in agreement with $\mathrm{Nd}$ and $\mathrm{Pb}-\mathrm{Pb}$ ages around 2.1 Ga (Silva, 1992).

To the west, the Gavião block (Fig. 1) contains the oldest Archean relics known in South America (Martin et al., 1991, 1997; Nutman and Cordani, 1993; Mougeot, 1996; Santos Pinto et al., 1998; Bastos Leal et al., 1998; Teixeira et al., 2000). It is composed of medium-grade Archean primitive continental crust (TTG), dated by zircon in the range of 3.23.4 Ga, and 2.7 Ga recycled granitoids. Several supracrustal 


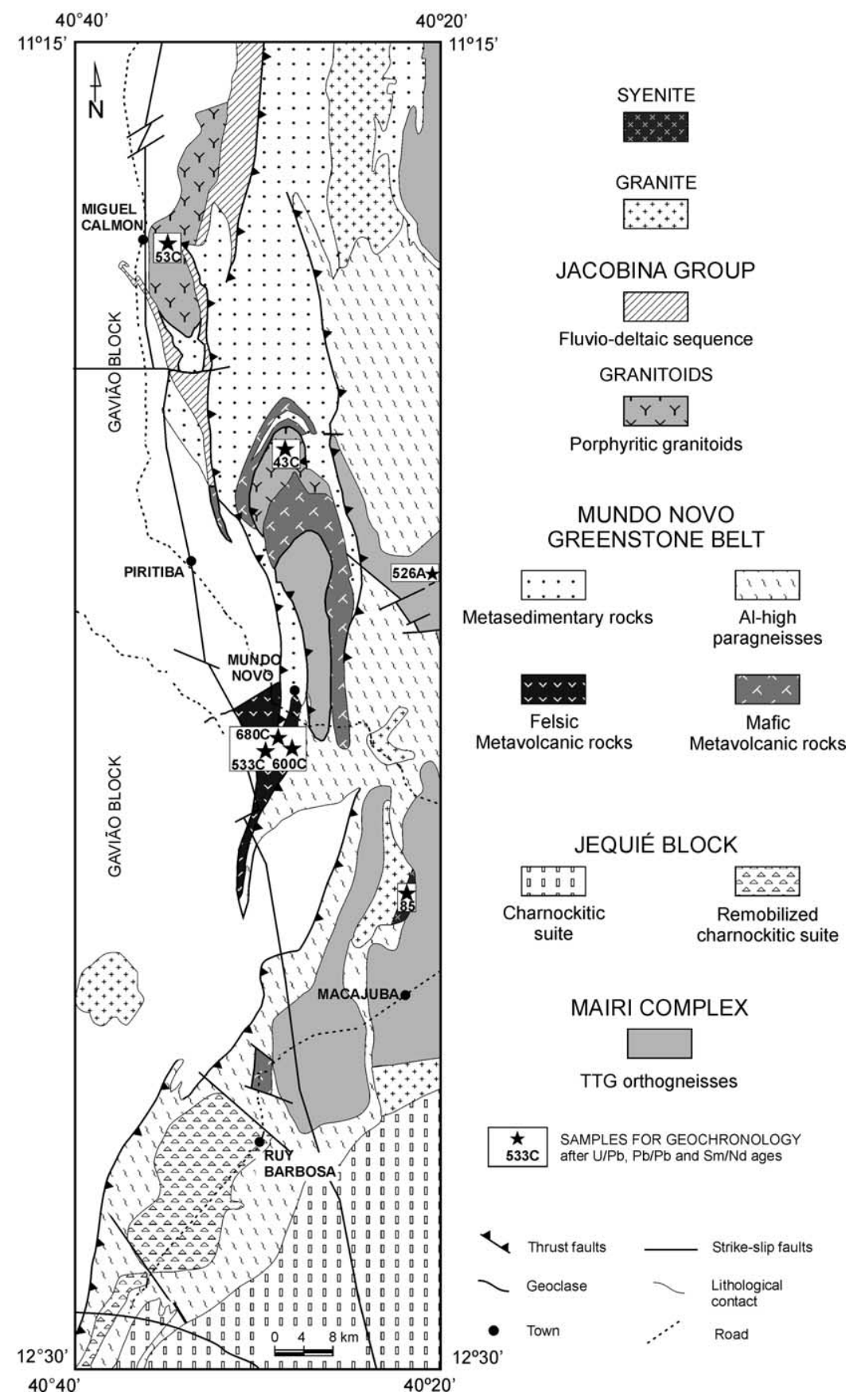

Fig. 2. Geological map of the southern part of the Mundo Novo greenstone belt (from Souza, in prep.).

belts in the Gavião block were described by the Companhia Baiana de Pesquisa Mineral (CBPM) programs as greenstone belts of possible Archean or Paleoproterozoic age; they make up the belts of Brumado, Umburanas, Contendas-Mirante, and Riacho de Santana (Cunha and Froes, 1994; Cunha et al., 1996; Peixoto et al., 1996). These supracrustal belts are dated by zircon, $\mathrm{Pb}-\mathrm{Pb}$ whole-rock, and Sm-Nd methods as 3.3-2.5 Ga (Wilson, 1987; Wilson et al., 1988; Marinho, 1991; Marinho et al., 1994; Bastos Leal et al., 1998). The greenstone belts are composed of metamorphosed mafic and ultramafic metavolcanic rocks, including komatiites with spinifex texture and tholeiitic basalts in the lower part, felsic metavolcanics and pyroclastic flows interbedded with scarce metasediments in the middle part, and iron-rich (BIF) and calcareous sediments at the top (Cunha and Froes, 1994). During the early Paleoproterozoic, the Gavião block underwent intensive migmatization, and related anatectic granites were emplaced at around 2.1-2.0 Ga. They indicate major crustal thickening at that time (Santos Pinto et al., 1998; Bastos Leal et al., 2000). The Gavião block and the eastern granulitic terrains are separated by a linear tectonic structure 
$600 \mathrm{~km}$ long (Contendas-Jacobina lineament, Sabaté et al., 1990). The Jacobina-Mundo Novo and Contendas-Mirante supracrustal belts follow this boundary in the eastern part of the Gavião block (Marinho, 1991; Sabaté et al., 1990, 1994a,b).

The Jequié block (B in Fig. 1) and the ItabunaSalvador-Curaçá belt (E in Fig. 1) are made up of charnockites with Archean and Paleoproterozoic magmatic protoliths dated by $\mathrm{U}-\mathrm{Pb}$ zircon at $2.8,2.6$, and $2.1 \mathrm{Ga}$ (Barbosa, 1990; Alibert and Barbosa, 1992; Marinho et al., 1994; Sabaté et al., 1994a,b; Ledru et al., 1994). Granulitic supracrustals, tectonically mixed with the charnockites, are also recognized. Granulite facies metamorphism is dated at approximately $2.1 \mathrm{Ga}$, and a previous high-grade event is suggested (Wilson, 1987; Wilson et al., 1988; Barbosa, 1990, 1996; Marinho et al., 1994; Ledru et al., 1994; Sabaté et al., 1994a,b).

The Mundo Novo greenstone belt and the Jacobina group (Figs. 1 and 2) are often interpreted as a single Paleoproterozoic basin known as the Jacobina basin (Couto et al., 1978; Ledru et al., 1997). The two units are bounded to the west by the $3.4 \mathrm{Ga}$ Gavião basement of TTG affinity (Mougeot, 1996) and to the east by the Mairi gneissic complex. The latter is a TTG/tholeiitic bimodal suite dated at ca. 3.0 Ga by $\mathrm{Rb}-\mathrm{Sr}$ (Brito Neves et al., 1980) and is considered part of the Gavião block (Sabaté, 1996; Barbosa and Sabaté, 2002). The Mundo Novo supracrustal belt (Fig. 2) is one of the most complete volcano sedimentary belts in the adjoining Gavião block (Mascarenhas and Silva, 1994). It crops out from the south of Mundo Novo City to Juazeiro City in the northernmost part of Bahia. From the base to the top, it is mainly composed of the following (Souza et al., 1996; Fig. 2):

1. Mafic metavolcanics formed mainly of basalts with pillow-lava structures (Roig et al., 1992), andesitic metabasalts, cherts, BIF, calcsilicate rocks, and graphitic schists; ultramafic tectonic slices intercalated within the Jacobina group are interpreted to belong to the greenstone belt. Metamorphism is of medium-grade and associated with sillimanite-bearing granites.

2. Felsic metavolcanics of dacitic and rhyodacitic composition with variolitic texture (cf. sample SSR 680c in this geochronological study), associated with pyroclastic metasediments, south of Mundo Novo.

3. Clastic to chemical metasedimentary rocks, including the Bananeiras Formation (iron- and manganese-rich pelitic schists and quartzite, Leo et al., 1964; Mascarenhas, 1969); the Agua Branca Formation (quartzite, quartziferous schists, phyllites, BIF, and associated Mn mineralization, Griffon, 1967); part of the Itapicuru complex (chemical and volcano sedimentary deposits, Loureiro and Santos, 1991); the Brejo dos Paulos Formation (ferriferous quartzites, gondites, calcsilicate, and mafic and ultramafic rocks, Arcanjo and Couto, 1978); and the Cruz das Almas Formation (conglomerates, quartzites, metasiltstones, and $\mathrm{Fe}-\mathrm{Mn}$-rich metapelites), which is alternatively interpreted as a lateral equivalent of the Bananeiras Formation (Leo et al., 1964; Couto et al., 1978) or correspondent to the top of the Jacobina group (Cox, 1967; Mascarenhas et al., 1992).

4. To the east of the Mundo Novo greenstone belt, Al-rich gneisses (kinzigites and cordierite-sillimanite-bearing gneisses) in close association with peraluminous granites. Such an association has recently been interpreted as a tectonic slice (originating in the Itabuna-SalvadorCuraçá belt) that contains the products of dehydration melting processes of the Trans-Amazonian orogeny, namely, restitic residues (Al-rich gneisses) and anatectic liquids (peraluminous granites) (Leite, in prep.).

To the west of the greenstone belt, according to the interpretation of Mascarenhas and Silva (1994), the metasedimentary fluvio-deltaic and marine units of the Jacobina group (Leo et al., 1964) are restricted from the base to the top to the following: (1) the Serra do Corrego conglomeratic and quartzitic formations containing economic gold deposits that appear to be derived from the greenstone belt, (2) the Rio do Ouro quartzites with intercalations of conglomerates and aluminous schists, and (3) the metapelites and quartzites of Cruz das Almas and quartzites and phyllites of the Serra da Paciência (Mascarenhas et al., 1992).

The Mundo Novo greenstone belt and the Jacobina group show amphibolite facies paragenesis related to two phases of metamorphism: the first is of Barrovian type (medium pressure/temperature) with garnet-, staurolite-, and epidotebearing assemblages, and the second is of low pressure and high-temperature type (LP/HT) with andalusite- and sillimanite-bearing assemblages. This metamorphic history is related to crustal thickening and the intrusion of peraluminous magmas during the Trans-Amazonian orogeny around 2.1-2.0 Ga (Leite, in prep.). Local variations in metamorphic conditions are related to shearing, as in zones with kyanite-bearing (higher pressures) or garnet (spessartite type) paragenesis. The muscovite- and chloritebearing zones imply hydration reactions under green schist facies conditions. The Al-high paragneiss are metamorphosed in the upper amphibolite/lower granulite facies (garnet-, sillimanite-, and cordierite-bearing assemblages).

The Mundo Novo greenstone belt and the Jacobina group are both included in tectonic slices related to a major eastto-west overthrusting associated with sinistral wrenching linked to Paleoproterozoic collisional processes (Leo et al, 1964; Griffon, 1967; Mascarenhas, 1969; Sabaté, 1996; Ledru et al., 1994, 1997). Mascarenhas and Silva (1994) describe interference folding in the greenstone belt that is not recognized in the Jacobina group. These authors suggest that the Mundo Novo greenstone belt could be older than the Jacobina sequence, possibly Archean. Ledru et al. (1994, 1997) also describe an even more complex tectonic evolution in some formations of the greenstone belt (Bananeiras and Cruz das Almas) where early foliation is 
preserved. However, these authors do not support the existence of units of significantly different ages.

A surrounding migmatitic gneissic basement to the west of the Jacobina sequence has been dated at 3.4 Ga (Mougeot et al., 1995; Mougeot, 1996), in agreement with the age obtained for the early stages of continental crust formation in the Gavião block (Martin et al., 1991, 1997; Nutman and Cordani, 1993). Some $\mathrm{Rb}-\mathrm{Sr}$ ages at 3.0 Ga, from the same gneissic basement, also support an Archean age, even if the systems were partially opened during Trans-Amazonian events (Couto et al., 1978; Mascarenhas and Garcia, 1989).

$\mathrm{A} \mathrm{Rb}-\mathrm{Sr}$ isochron age of $1.86 \mathrm{Ga}$ was obtained by Melo (1991) for the metadacites from the Mundo Novo greenstone belt, which is interpreted as the crystallization age. However, because the $\mathrm{Rb}-\mathrm{Sr}$ system in felsic volcanics is commonly reset and the age defined is in the same range or younger than the late granites, it may have been modified during Trans-Amazonian events, as was observed, for example, for the Contendas-Mirante felsic metavolcanics (Wilson, 1987; Marinho, 1991).

In the Jacobina group, $\mathrm{Rb}-\mathrm{Sr}$ whole-rock ages of 2.5 and $2.7 \mathrm{Ga}$ have been obtained for kyanite-bearing quartzites of the Serra do Corrego and phyllites of the Itapicuru complex (Mascarenhas, 1976). These isochron ages and the high initial ratios observed suggest an Archean protolith involved in the source of the sedimentary rocks. This interpretation is in agreement with the ages of detrital zircons from a conglomerate member of the Rio do Ouro Formation, in that $85 \%$ of the population is close to $3.4 \mathrm{Ga}$ and the rest yields mainly $2.15 \mathrm{Ga}$ (Mougeot et al., 1995). The youngest age obtained by Mougeot (1996) is $2086 \pm 43 \mathrm{Ma}$. This result provides a good estimate for sedimentation of the Jacobina group between $2086 \pm 43$ and $1969 \pm 29 \mathrm{Ma}$, the $\mathrm{Rb}-\mathrm{Sr}$ age of the Campo Formoso granite that cuts the Jacobina group (Sabaté et al., 1990). The ${ }^{40} \mathrm{Ar} /{ }^{39} \mathrm{Ar}$ mica ages of 1.91 and $1.94 \mathrm{Ga}$ are interpreted as minimum cooling ages of the major deformation observed in the Jacobina group (Ledru et al., 1997).

Ledru et al. (1997) interpret the Jacobina group, including the Mundo Novo greenstone belt, as a foreland basin developed during the Trans-Amazonian collision and corresponding to the overthrusting of the eastern Jequiétype granulitic terrain over the western lower-grade terrains. Mascarenhas and Silva (1994) interpret the Jacobina group as a graben related to rifting located around a greenstone belt of Archean or Paleoproterozoic age.

Three hypotheses may be forwarded about the age of the felsic volcanism of Mundo Novo. It may be related to crustal melting during Trans-Amazonian collisional processes and have an age close to $2.1 \mathrm{Ga}$, which is the hypothesis of a single-stage evolution of the Jacobina basin (Ledru et al., 1997). It may be related to an early stage of the Trans-Amazonian orogeny (rifting), with an age of ca. $2.2 \mathrm{Ga}$, as observed in the oldest volcanism of the Paleoproterozoic Rio Itapicuru greenstone belt farther east
(Silva, 1992). Finally, it may be even older and related to Archean tectono-metamorphic evolution.

\section{Methodology}

$\mathrm{U}-\mathrm{Pb}$ zircon analyses were made using SHRIMP I (Canberra ANU), and each analysis consisted of six scans through the mass range. The data have been reduced in a manner similar to that described by Williams (1998). The $\mathrm{Pb} / \mathrm{U}$ ratios have been normalized relative to a value of 0.1859 for the ${ }^{206} \mathrm{~Pb} /{ }^{238} \mathrm{U}$ ratio of the AS3 reference zircons, equivalent to an age of $1099 \mathrm{Ma}$ (Paces and Miller, 1993). Uncertainties for individual analyses (ratios and ages) are at the one $\sigma$ level, but the uncertainties in calculated weighted mean ages are reported as $95 \%$ confidence limits. Weighted mean ${ }^{207} \mathrm{~Pb} /{ }^{206} \mathrm{~Pb}$ ages were carried out using ISOPLOT/EX (Ludwig, 1999). ${ }^{207} \mathrm{~Pb} /{ }^{206} \mathrm{~Pb}$ zircon evaporation (Kober, 1986) TIMS analyses were performed on a Finnigan Mat 262 mass spectrometer at Géosciences Rennes-CNRS following classical procedures (Peucat et al., 1999). Replicate analyses for NBS 983 are as follows: ${ }^{206} \mathrm{~Pb} /{ }^{204} \mathrm{~Pb}=2763 \pm 2$ and ${ }^{207} \mathrm{~Pb} /{ }^{206} \mathrm{~Pb}=0.071247 \pm 3$. $\mathrm{Nd}$ and $\mathrm{Sr}$ analyses were performed in the Clermont Ferrand laboratory on a VG mass spectrometer using methods described by Martin et al. (1997). Nd model ages were calculated using $\epsilon_{\mathrm{Nd}}$ values of +8 for the present-day depleted mantle and ${ }^{147} \mathrm{Sm} /{ }^{144} \mathrm{Nd}=0.2137$, following a radiogenic linear growth for the mantle starting at $4.54 \mathrm{Ga}$, in agreement with Nägler and Kramers's (1998) model. For ${ }^{207} \mathrm{~Pb} /{ }^{206} \mathrm{~Pb}$ zircon evaporation ages, common lead for correction was assumed to have the composition calculated from the two-stage model of Stacey and Kramers (1975). Errors on ${ }^{207} \mathrm{~Pb} /{ }^{206} \mathrm{~Pb}$ ages are the weighted average at the $2 \sigma$ level of ages and errors obtained on independent runs of 20 ratios, using the Isoplot programme of Ludwig (1999). Each grain was analyzed at different temperature steps (low, high, and very high) corresponding, respectively, to currents of 2.6, 3.0, and 3.3 A (approximatively to 1480, 1540, and $1610 \pm 10^{\circ} \mathrm{C}$ ). All ages were calculated using the decay constants and isotopes abundances listed by Steiger and Jäger (1977).

\section{Geochronological results}

$\mathrm{Sr}$ and Nd whole-rock analyses were carried out on seven samples (Table 1). Zircon dating was performed by the evaporation method and SHRIMP (Tables 2 and 3) on felsic volcanites and on one enclosing gneiss by the evaporation method (Table 2).

Sample SSR 526A is a granodioritic gneiss from the Mairi complex (Fig. 2) located between the Mundo Novo greenstone belt and granulitic terrains of the Jequié block. It is contained within a TTG gneiss suite similar to that observed in the Gavião block. The $\mathrm{Nd} T_{\mathrm{DM}}$ age of $3.21 \mathrm{Ga}$ 
Table 1

$\mathrm{Sm}-\mathrm{Nd}$ and $\mathrm{Rb}-\mathrm{Sr}$ isotopic data for whole-rocks

\begin{tabular}{|c|c|c|c|c|c|c|c|c|c|c|c|c|c|c|c|c|c|c|}
\hline \multirow[t]{2}{*}{ Samples } & \multirow{2}{*}{$\begin{array}{l}\text { Sm } \\
(\mathrm{ppm})\end{array}$} & \multirow{2}{*}{$\begin{array}{l}\mathrm{Nd} \\
(\mathrm{ppm})\end{array}$} & \multirow[t]{2}{*}{${ }^{147} \mathrm{Sm} /{ }^{144} \mathrm{Nd}$} & \multirow[t]{2}{*}{${ }^{143} \mathrm{Nd} /{ }^{144} \mathrm{Nd}$} & \multirow{2}{*}{$\begin{array}{l}\text { Error } \\
\times 10^{-6}\end{array}$} & \multirow{2}{*}{$\begin{array}{l}\epsilon \\
\mathrm{Nd}_{0} \\
\text { at: } \\
0 \mathrm{Ga}\end{array}$} & \multirow{2}{*}{$\begin{array}{l}T_{\mathrm{DM}} \\
\left(\epsilon_{0}=8\right) \\
\text { in } \mathrm{Ga}\end{array}$} & \multicolumn{3}{|c|}{$\epsilon \mathrm{Nd}_{0}$ at: } & \multirow{2}{*}{$\begin{array}{l}\mathrm{Rb} \\
(\mathrm{ppm})\end{array}$} & \multirow{2}{*}{$\begin{array}{l}\text { Sr } \\
\text { (ppm) }\end{array}$} & \multirow[t]{2}{*}{${ }^{87} \mathrm{Rb} /{ }^{86} \mathrm{Sr}$} & \multirow[t]{2}{*}{${ }^{87} \mathrm{Sr} /{ }^{86} \mathrm{Sr}$} & \multirow[t]{2}{*}{ Error $\times 10^{-6}$} & \multicolumn{3}{|l|}{$I_{0} \mathrm{Sr}$ at: } \\
\hline & & & & & & & & $3.3 \mathrm{Ga}$ & $3.1 \mathrm{Ga}$ & $2.1 \mathrm{Ga}$ & & & & & & $3.3 \mathrm{Ga}$ & $3.1 \mathrm{Ga}$ & $2.1 \mathrm{Ga}$ \\
\hline \multicolumn{19}{|c|}{ Gneiss of the Mairi complex: } \\
\hline $\begin{array}{l}\text { SSR } \\
526 \mathrm{~A}\end{array}$ & 2.16 & 15.0 & 0.0869 & 0.510357 & 11 & -45 & 3.21 & - & -2 & - & 92 & 350 & 0.761 & 0.736043 & 18 & - & 0.703 & \\
\hline \multicolumn{19}{|c|}{ Metadacites of the Mundo Novo greenstone belt: } \\
\hline $\begin{array}{l}\text { SSR } \\
600\end{array}$ & 10.0 & 49.3 & 0.1231 & 0.511044 & 7 & -31 & 3.35 & 0 & - & - & 44 & 45 & 2.82 & 0.832663 & 15 & 0.698 & - & - \\
\hline $\begin{array}{l}\text { SSR } \\
533 C\end{array}$ & 13.9 & 69.3 & 0.1216 & 0.510992 & 7 & -32 & 3.38 & 0 & - & - & 123 & 18 & 19.8 & 1.716713 & 7 & 0.768 & - & - \\
\hline $\begin{array}{l}\text { SSR } \\
680 \mathrm{C}\end{array}$ & 9.70 & 48.0 & 0.1223 & 0.511005 & 11 & -32 & 3.38 & 0 & - & - & 52 & 61 & 2.47 & 0.837013 & 14 & 0.719 & - & - \\
\hline \multicolumn{19}{|c|}{ Miguel Calmon granite: } \\
\hline $\begin{array}{l}\text { SSR } \\
53 \mathrm{C}\end{array}$ & 2.83 & 22.7 & 0.0753 & 0.509978 & 8 & -52 & 3.36 & - & - & -19 & 92 & 519 & 0.513 & 0.730017 & 13 & - & - & 0.714 \\
\hline Areia Bra & nca orth & gneiss: & & & & & & & & & & & & & & & & \\
\hline $\begin{array}{l}\text { SSR } \\
43 C\end{array}$ & 7.42 & 57.6 & 0.0780 & 0.510884 & 10 & -34 & 2.42 & - & - & -2 & 184 & 137 & 3.88 & 0.885286 & 8 & - & - & 0.768 \\
\hline $\begin{array}{l}\text { Syenite: } \\
\text { SSR } 85\end{array}$ & 16.4 & 130 & 0.0763 & 0.510560 & 6 & -41 & 2.75 & - & - & -8 & 193 & 1026 & 0.545 & 0.719618 & 19 & - & - & 0.703 \\
\hline
\end{tabular}


Table 2

Summary of TIMS $\mathrm{Pb}$ evaporation zircon isotopic data

\begin{tabular}{|c|c|c|c|c|c|c|c|c|}
\hline Samples & $\begin{array}{l}\text { Step intensity } \\
\text { in ampere }\end{array}$ & $\begin{array}{l}n \text { ratios } \\
\text { measured }\end{array}$ & $\begin{array}{l}{ }^{206} \mathrm{~Pb} /{ }^{204} \mathrm{~Pb} \\
\text { measured }\end{array}$ & $\begin{array}{l}{ }^{207} \mathrm{~Pb} /{ }^{206} \mathrm{~Pb} \\
\text { measured }\end{array}$ & $\begin{array}{l}\text { Error } 2 \\
\sigma \mathrm{m} \times 10^{-4}\end{array}$ & $\begin{array}{l}{ }^{207} \mathrm{~Pb} /{ }^{206} \mathrm{~Pb} \\
\text { corrected }\end{array}$ & $\begin{array}{l}{ }^{207} \mathrm{~Pb} /{ }^{206} \mathrm{~Pb} \text { age } \\
(\mathrm{Ma})\end{array}$ & $\begin{array}{l}\text { Weighted } 2 \\
\sigma \text { error } \pm \text { (in } \mathrm{Ma})\end{array}$ \\
\hline \multicolumn{9}{|c|}{ Mairi gneiss (SSR 526 A) } \\
\hline \multirow[t]{4}{*}{9 Euhedral gra } & 3.0 & $100^{\mathrm{a}}$ & 1827 & 0.2318 & 5 & 0.2261 & 3025 & 22 \\
\hline & 3.0 & 100 & 1890 & 0.2343 & 5 & 0.2288 & 3043 & 25 \\
\hline & 3.3 & $40^{\mathrm{a}}$ & 1922 & 0.2332 & 6 & 0.2278 & 3040 & 15 \\
\hline & & 240 & 1869 & 0.2331 & & Average: & 3040 & 15 \\
\hline \multicolumn{9}{|c|}{ Metadacite (SSR 680 C) } \\
\hline 7 Euhedral gra & 2.6 & 120 & 2920 & 0.2595 & 3.7 & 0.2558 & 3220 & 6 \\
\hline 6 Euhedral gra & 2.6 & 100 & 7498 & 0.2625 & 1.6 & 0.2611 & 3254 & 2 \\
\hline
\end{tabular}

All runs have been recorded using an ion counting process.

${ }^{\text {a }}$ Low intensity run $\left(<5000\right.$ counts on $\left.{ }^{206} \mathrm{~Pb}\right)$.

(Table 1) represents the maximum age of extraction of the protolith from the mantle, unless it results from mixing processes involving components of various ages. Zircon dating was performed by the evaporation method, but we were unsuccessful for single grains and had to use several grains during the lead ionization procedure. We obtained a range of ${ }^{207} \mathrm{~Pb} /{ }^{206} \mathrm{~Pb}$ ages between $3025 \pm 22$ and $3040 \pm 15 \mathrm{Ma}$ (Table 2). We interpret the zircon age of $3040 \pm 15 \mathrm{Ma}$ as the minimum age of crystallization, in accordance with the $\mathrm{Nd}$ evidence of an Archean protolith. This age is in agreement with the $\mathrm{Rb}-\mathrm{Sr}$ whole-rocks ages of ca 3.0 Ga by Couto et al. (1978) and Mascarenhas and Garcia (1989). The negative $\epsilon_{\mathrm{Nd}}$ ratio $(-2)$ and high $87 \mathrm{Sr} /$ 86SSr (0.703) (Table 1) at $3.04 \mathrm{Ga}$ (zircon age) suggest either crustal reworking or an older age for crystallization of the granodioritic magmas.

Sample SSR 680C, typical of the felsic volcanic rocks of the Mundo Novo greenstone belt, is a porphyritic metadacite with a microporphyritic texture. Phenocrysts are ca. 1$2 \mathrm{~mm}$ in size and composed of round quartz, subeuhedral to slightly deformed plagioclase (fusiform structures), and altered green biotite. The quartzo-feldspatic (quartz, plagioclase, microcline) ground mass is fine grained and slightly foliated. Amygdals of quartz are also observed. The metadacitic samples SSR 600, SSR 533C, and SSR 680C have similar Nd signatures, thus yielding model ages of ca. $3.4 \mathrm{Ga}$ (Table 1). The $\mathrm{Sr}$ isotope compositions calculated are heterogeneous and clearly disturbed, with values either lower than 0.700 or very high (up to 0.768 ). Zircon dating was performed on sample SSR 680C by the evaporation method and SHRIMP. Zircons are euhedral and of hightemperature type (S25-J5 of Pupin (1980)) without any evidence of inherited cores (Fig. 3). They are relatively large but have abundant gas vapor trails, which are diagnostic of rapid cooling. Whereas the cathodoluminescence shows simple magmatic zoning, the transmitted light photomicrographs show abundant cavities consistent with a volcanic to subvolcanic paragenesis. Here again, we used several grains to obtain a significant amount of radiogenic lead during the evaporation procedure. The first set of data provides a ${ }^{207} \mathrm{~Pb} /{ }^{206} \mathrm{~Pb}$ age of $3220 \pm 6 \mathrm{Ma}$; another set yields $3254 \pm 2 \mathrm{Ma}$. This result suggests an Archean age of the zircons, but the range of ages observed (30 Ma) suggests some further lead loss. The oldest age is interpreted as a minimum age for the magmatic crystallization. To define this age more precisely, we performed $\mathrm{U}-\mathrm{Pb}$ dating by ion microprobe (SHRIMP). The data from the 17 analyzed grains are subconcordant in the Concordia diagram (Fig. 3) and define an average ${ }^{207} \mathrm{~Pb} /{ }^{206} \mathrm{~Pb}$ age of $3305 \pm 9 \mathrm{Ma}$, which is the age of the felsic volcanic metadacite event. It is also similar to the $\mathrm{Nd}$ model ages obtained for the same rocks and suggests that felsic volcanism is related to a stage of accretion of juvenile continental crust.

Sample SSR 53C corresponds to the Miguel Calmon granite, which is a Paleoproterozoic pluton emplaced within the Archean Gavião basement and the Jacobina group on the western side of the greenstone belt (Fig. 2). The Nd model age of $3.36 \mathrm{Ga}$ indicates that this granite is mainly derived from an Archean source, probably corresponding to the $3.4 \mathrm{Ga}$ Gavião basement, which is also suggested by the high $\mathrm{Sr}(0.714$, Table 1) initial ratio calculated at $2.10 \mathrm{Ga}$.

Sample SSR 43C corresponds to the Areia Branca orthogneiss. Its $\mathrm{Nd}$ model age of $2.42 \mathrm{Ga}$ indicates a different source from the previous granite and suggests that the protolith may have resulted from the mixing between Archean and Proterozoic components. As such, it is a maximum age for the magmatic stage and probably related to the Trans-Amazonian orogeny at approximately $2.1 \mathrm{Ga}$. The $\mathrm{Sr}$ initial ratio at $2.1 \mathrm{Ga}$ is very high $(0.768$, Table 1$)$, which indicates the $\mathrm{Rb}-\mathrm{Sr}$ system was disturbed.

Sample SSR 85 is a syenite that probably corresponds to the late Trans-Amazonian alkaline magmatism in the SFC that has been dated at $2004 \pm 32 \mathrm{Ma}$ (Conceição et al., 1997) and $2030 \pm 6 \mathrm{Ma}$ (Peucat et al., unpublished) by evaporation on zircons $\left({ }^{207} \mathrm{~Pb} /{ }^{206} \mathrm{~Pb}\right.$ ages $)$ from the Itiüba batholith. Taking into account this age, the $\mathrm{Nd}$ isotopic system with a $T_{\mathrm{DM}}$ model age of $2.75 \mathrm{Ga}$ and negative $\epsilon_{\mathrm{Nd}}$ ratio at $2.03 \mathrm{Ga}(-8)$ obtained for sample SSR 85 (Table 1) suggest an Archean component mixed with the alkaline Proterozoic source. The $\mathrm{Sr}$ initial ratio of 0.703 at $2.03 \mathrm{Ga}$ 
Table 3

Summary of SHRIMP U-Pb zircon results for sample SSR680c

\begin{tabular}{|c|c|c|c|c|c|c|c|c|c|c|c|c|c|c|c|c|c|c|c|}
\hline \multirow[t]{2}{*}{ Grain spot } & \multirow[t]{2}{*}{$\begin{array}{l}\mathrm{U} \\
(\mathrm{ppm})\end{array}$} & \multirow[t]{2}{*}{$\begin{array}{l}\text { Th } \\
(\mathrm{ppm})\end{array}$} & \multirow[t]{2}{*}{$\mathrm{Th} / \mathrm{U}$} & \multirow[t]{2}{*}{$\begin{array}{l}\mathrm{Pb}^{*} \\
(\mathrm{ppm})\end{array}$} & \multirow[t]{2}{*}{${ }^{204} \mathrm{~Pb} /{ }^{206} \mathrm{~Pb}$} & \multirow[t]{2}{*}{$\begin{array}{l}f_{206} \\
(\%)\end{array}$} & \multicolumn{6}{|c|}{ Radiogenic ratios } & \multicolumn{6}{|l|}{$\begin{array}{l}\text { Ages } \\
\text { (in Ma) }\end{array}$} & \multirow[t]{2}{*}{$\begin{array}{l}\text { Con } \\
(\%)\end{array}$} \\
\hline & & & & & & & ${ }^{206} \mathrm{~Pb} /{ }^{238} \mathrm{U}$ & \pm & ${ }^{207} \mathrm{~Pb} /{ }^{235} \mathrm{U}$ & \pm & ${ }^{207} \mathrm{~Pb} /{ }^{206} \mathrm{~Pb}$ & \pm & ${ }^{206} \mathrm{~Pb} /{ }^{238} \mathrm{U}$ & \pm & ${ }^{207} \mathrm{~Pb} /{ }^{235} \mathrm{U}$ & \pm & ${ }^{207} \mathrm{~Pb} /{ }^{206} \mathrm{~Pb}$ & \pm & \\
\hline 1.1 & 112 & 62 & 0.55 & 35 & 0.000714 & 0.88 & 0.6789 & 0.0158 & 25.13 & 0.72 & 0.2684 & 0.0037 & 3340 & 61 & 3313 & 28 & 3297 & 22 & 101 \\
\hline 2.1 & 119 & 72 & 0.61 & 37 & 0.001493 & 1.83 & 0.6645 & 0.0168 & 24.28 & 0.74 & 0.2650 & 0.0037 & 3285 & 66 & 3280 & 30 & 3277 & 22 & 100 \\
\hline 3.1 & 158 & 88 & 0.56 & 47 & 0.001003 & 1.23 & 0.6497 & 0.0137 & 24.06 & 0.64 & 0.2686 & 0.0036 & 3227 & 54 & 3271 & 26 & 3298 & 21 & 98 \\
\hline 4.1 & 112 & 54 & 0.48 & 34 & 0.002141 & 2.63 & 0.6806 & 0.0251 & 24.74 & 1.10 & 0.2636 & 0.0054 & 3347 & 97 & 3298 & 44 & 3268 & 33 & 102 \\
\hline 5.1 & 154 & 98 & 0.64 & 47 & 0.000930 & 1.14 & 0.6556 & 0.0197 & 24.38 & 0.85 & 0.2697 & 0.0038 & 3250 & 77 & 3284 & 34 & 3304 & 22 & 98 \\
\hline 6.1 & 158 & 103 & 0.65 & 49 & 0.001029 & 1.26 & 0.6596 & 0.0203 & 24.74 & 0.89 & 0.2721 & 0.0040 & 3266 & 79 & 3298 & 36 & 3318 & 23 & 98 \\
\hline 7.1 & 104 & 42 & 0.40 & 28 & 0.001746 & 2.14 & 0.6002 & 0.0203 & 22.15 & 0.90 & 0.2676 & 0.0051 & 3031 & 82 & 3190 & 40 & 3292 & 30 & 92 \\
\hline 8.1 & 166 & 113 & 0.68 & 53 & 0.001499 & 1.84 & 0.6811 & 0.0176 & 25.27 & 0.73 & 0.2690 & 0.0027 & 3349 & 68 & 3319 & 29 & 3300 & 16 & 102 \\
\hline 9.1 & 128 & 66 & 0.52 & 38 & 0.001716 & 2.11 & 0.6664 & 0.0232 & 24.80 & 0.99 & 0.2699 & 0.0041 & 3292 & 90 & 3300 & 40 & 3305 & 24 & 100 \\
\hline 10.1 & 84 & 38 & 0.45 & 24 & 0.002638 & 3.24 & 0.6328 & 0.0198 & 23.45 & 0.91 & 0.2688 & 0.0053 & 3161 & 78 & 3246 & 39 & 3299 & 31 & 96 \\
\hline 11.1 & 164 & 99 & 0.60 & 49 & 0.001974 & 2.42 & 0.6501 & 0.0156 & 23.88 & 0.68 & 0.2664 & 0.0035 & 3229 & 61 & 3263 & 28 & 3285 & 20 & 98 \\
\hline 12.1 & 115 & 61 & 0.53 & 35 & 0.002202 & 2.70 & 0.6523 & 0.0190 & 24.84 & 0.85 & 0.2761 & 0.0040 & 3237 & 75 & 3302 & 34 & 3341 & 23 & 97 \\
\hline 13.1 & 166 & 110 & 0.66 & 51 & 0.000777 & 0.96 & 0.6600 & 0.0213 & 24.56 & 0.87 & 0.2699 & 0.0029 & 3267 & 83 & 3291 & 35 & 3306 & 17 & 99 \\
\hline 14.1 & 141 & 71 & 0.51 & 44 & 0.001743 & 2.14 & 0.6814 & 0.0190 & 25.40 & 0.85 & 0.2704 & 0.0041 & 3350 & 73 & 3324 & 33 & 3308 & 24 & 101 \\
\hline 15.1 & 129 & 81 & 0.63 & 41 & 0.000276 & 0.34 & 0.6858 & 0.0144 & 25.72 & 0.59 & 0.2720 & 0.0019 & 3367 & 55 & 3336 & 23 & 3318 & 11 & 102 \\
\hline 16.1 & 76 & 34 & 0.45 & 24 & 0.000202 & 0.25 & 0.6929 & 0.0145 & 26.01 & 0.62 & 0.2722 & 0.0025 & 3394 & 56 & 3347 & 24 & 3319 & 14 & 102 \\
\hline
\end{tabular}

Uncertainties given at the one $\sigma$ level. $f_{206} \%$ denotes the percentage of ${ }^{206} \mathrm{~Pb}$ that is common $\mathrm{Pb}$. Correction for common $\mathrm{Pb}$ made using the ${ }^{204} \mathrm{~Pb} /{ }^{206} \mathrm{~Pb}$ ratio. Conc. (100\%) denotes a concordant analysis. 


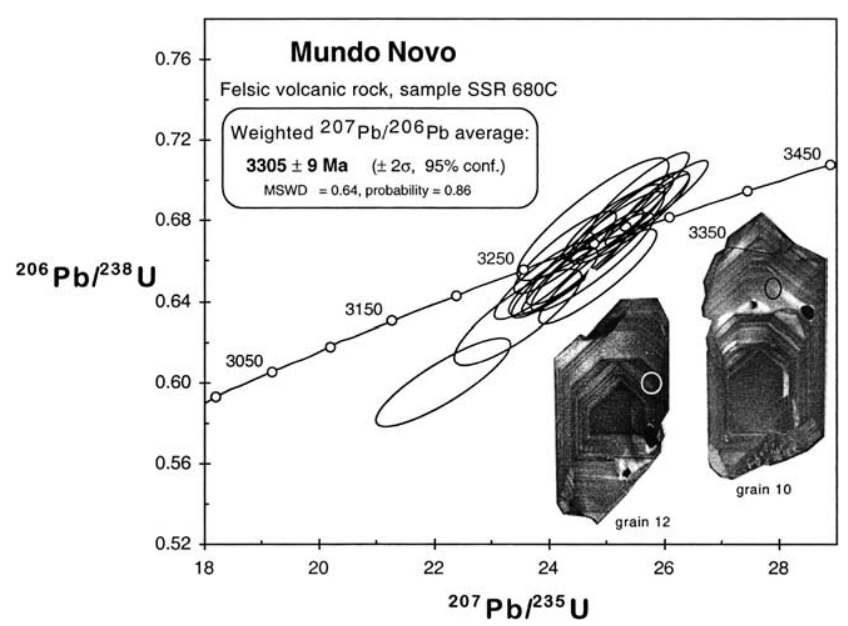

Fig. 3. U-Pb concordia plot of the SHRIMP ion probe data for the Mundo Novo felsic volcanic rock, sample SSR 680C, and cathodoluminescence images of two analyzed SHRIMP grains. Magmatic zoning and large development of the (101) pyramid are clear, as are the SHRIMP pits $(30 \mu \mathrm{m}$ in diameter).

(Table 1) would indicate a mantle-derived component of the syenitic magmatic stage. Alternatively, the syenite could be derived from a REE-enriched mantle source at $2.03 \mathrm{Ga}$ with the $T_{\mathrm{DM}} \mathrm{Nd}$ model age not significant, but the $\epsilon_{\mathrm{Nd}}$ of $(-8)$ is probably a stronger negative value at $2.03 \mathrm{Ga}$, in support of this hypothesis.

\section{Discussion and conclusion}

The $\mathrm{U}-\mathrm{Pb}$ zircon SHRIMP age of $3305 \pm 9 \mathrm{Ma}$ obtained for the felsic metavolcanic rock of Mundo Novo greenstone belt is interpreted as recording a juvenile magmatic stage. This age probably defines the formation of the Mundo Novo greenstone belt and is assumed to be in the same range as the associated metabasalts, BIF, cherts, and other rocks. The economic gold deposit of the Jacobina basin is considered derived from the greenstone belt (Mascarenhas and Silva, 1994), and consequently, its source is Archean. To the east of the greenstone belt, a granodioritic gneiss belonging to the Mairi complex yields an Archean age that is slightly younger than the Mundo Novo felsic volcanism. These Mairi gneisses are similar in age to some gneisses of the Gavião block farther west (Santos Pinto et al., 1998). From a geochronological point of view, this establishes the existence of three major units in the Jacobina region: the $3.3 \mathrm{Ga}$ greenstone belt, the 3.03.2 Ga eastern Mairi gneisses, and the $2.1 \mathrm{Ga}$ Jacobina sedimentary basin.

The second set of conclusions pertains to similarities that can be established for the southern Contendas-Mirante belt (Fig. 1). This belt is made up of several units of different ages (Marinho, 1991; Marinho et al., 1994). The lower unit is very similar to the Mundo Novo greenstone belt, with basaltic and felsic metavolcanic rocks, metacherts, BIF, marble, calc-schists, and detrital metasediments. The felsic metavolcanics yield a $\mathrm{U}-\mathrm{Pb}$ zircon age of $3304 \pm 31 \mathrm{Ma}$ and $\mathrm{Nd}$ crustal residence ages of 3.3-3.4 Ga (Marinho et al., 1994), in the range of the results obtained for the Mundo Novo metadacites. The upper unit is a detrital sedimentary formation (Areião Formation), mainly fluvio-deltaic, similar to the Paleoproterozoic Jacobina basin. A conglomerate from the upper unit (Nutman et al., 1994) has yielded detrital zircon ages at ca $2.7 \mathrm{Ga}$ (Jequié type) and $2.15 \mathrm{Ga}$. The oldest inherited zircons differ from those found in the Jacobina sequence (Mougeot, 1996), which are mainly 3.4 Ga (Gavião type). This indicates that different Archean sources were involved in the ca. 2.1 Ga sedimentary basin, probably according to the proximity of the corresponding basements.

The last conclusion implies that the Paleoproterozoic basin follows the trend of ancient Archean greenstone belts over a distance of ca. $600 \mathrm{~km}$. According to the model of Ledru et al. (1997), a flexure of the lithosphere would have occurred to the west of a thickened lithosphere during the Trans-Amazonian collision, leading to the development of foreland basins in which the Jacobina group and Areião Formation were accumulated. We postulate that this flexure was developed along a zone of weakness that corresponds to the occurrence of the Archean greenstone belts. These probably induced rheological contrasts in the continental crust at the eastern margin of the Gavião block. The zone of tectonic weakness would correspond with the so-called Contendas-Jacobina lineament of Sabaté et al. (1990, 1996), which would have reused an old Archean structure.

\section{Acknowledgments}

This research was funded by CNPq, CAPES-COFECUB collaborative project, and CBPM, which also provided logistic support. Professor H. Martin of the Clermont Ferrand University (France) is thanked for $\mathrm{Rb}-\mathrm{Sr}$ and $\mathrm{Sm}-$ $\mathrm{Nd}$ analyses. Dc MSN Carpenter is acknowledged for revising the English manuscript. Professors L.A. Hartmann and W. Teixeira are thanked for their stimulating and helpful comments.

\section{References}

Alibert, C., Barbosa, J.F.S., 1992. Ages U-Pb déterminés à la SHRIMP sur des zircons du complexe de Jequié, Craton de São Francisco, Bahia, Brésil, IVè Réunion des Sciences de la Terre, vol. 14. Société Géologique de France, Toulouse, p. 142.

Arcanjo, J.B.A., Couto, P.A., 1978. Anomalias de cromo e niquel associadas ao complexo máfico-ultramáfico de Brejo dos Paulos (Ba), Congresso Brasileiro de Geologia, SGB, Anais, Recife, vol. 5., pp. 1960-1968.

Barbosa, J.S.F., 1990. The granulites of the Jequie complex and Atlantic mobile belt, southern Bahia, Brazil. An expression of Archean 
Proterozoic plate convergence. In: Vielzeuf, D., Vidal, P. (Eds.), Granulites and Crustal Evolution, NATO ASI series. Serie C, vol. 311., pp. 195-221.

Barbosa, J.S.F., 1996. O embasamento arqueano e proterozóico inferior do Estado da Bahia. In: Barbosa, J.S.F., Domingues, J.M.L. (Eds.), Mapa Geológico do Estado da Bahia, Texto Explicativo, Escala 1/1,000,000, Governo do Estado da Bahia/Universidade Federal da Bahia, Salvador, pp. 64-85.

Barbosa, J.S.F., Sabaté, P., 2002. Geological features and the Paleoproterozoic collision of the four Archean crustal segments of the São Francisco craton, Bahia, Brazil. A synthesis. Revista da Academia Brasileira de Ciencias in press.

Bastos Leal, L.R., 1992. Geocronologia Rb-Sr e K-Ar, evolução isotópica e implicações tectônicas dos enxames de diques máficos de Uauá e vale do Rio Curaçá, Bahia. Dissertação de Mestrado Instituto de Geociências, Universidade de São Paulo, 118 p.

Bastos Leal, L.R., Teixeira, W., Cunha, J.C., Macambira, M.J.B., 1998. Archean tonalitic-trondhjemitc and granitic plutonism in the Gavião block, São Francisco craton, Bahia, Brazil: geochemical and geochronological characteristics. Revista Brasileira de Geosciêncas 2 (2), 209-220.

Bastos Leal, L.R., Teixeira, W., Cunha, J.C., Menezes Leal, A.B., Macambira, M.J.B., Silva Rosa, M.L., 2000. Isotopic signatures of the Paleoproterozoic granitoids of the Gavião Block and implications for the evolution of the São Francisco craton, Bahia, Brazil. Revista Brasileira de Geociêncas 30 (1), 66-69.

Brito Neves, B.B., Cordani, U.G., Torquato, R.J., 1980. Evolução geocronológica do Precambriano do estado da Bahia. Texto BásicosBa, SME/CPM 3, pp. 1-101.

Conceição, H., Martin, H., Rosa, M.L.S., Conceição, R.V., Sabaté, P., 1997. Alkali-potassic magmas generated by partial melting of Na-enriched mantle source: example from the lower Proterozoic plutonism from the state of Bahia, NE Brazil. International Symposium on Granites and associated mineralisation. Salvador, Bahia, Brazil. Extended Abstract, pp. $108-109$.

Couto, P.A., Sampaio, A.R., Gil, C.A.A., Loureiro, H.C., Arcanjo, J.B., Fernandes Filho, J.F., Guimaraes, J.T., Melo, R.C., 1978. Projeto Serra de Jacobina: geologia e prospecção geoquimica, relatório final, Salvador. CPRM, Convênio DNPM-CPRM, 12v.

Cox, D.P., 1967. Regional environment of the Jacobina auriferous conglomerate. Economic Geology 62, 773-780.

Cunha, J.C., Froés, R.J.B., 1994. Komatiitos com textura spinifex do Greenstone Belt de Umburanas, Bahia. Série Arquivos Abertos No. 7. Companhia Baiana de Pesquisa Mineral-CBPM, Salvador, ils, mapas, pp. $1-29$.

Cunha, J.C., Bastos Leal, L.R., Froés, R.J.B., Teixeira, W., Macambira, M.J.B., 1996. Idade dos greenstone belts e dos terrenos TTGs associados da região do Craton do São Francisco (Bahia, Brasil), Congresso Brasileiro de Geologia. 39 Anais, Salvador, vol. 1., pp. 6265 .

Davison, I., Teixeira, J.B.G., Silva, M.G., Neto, M.B.R., Matos, F.M.V., 1988. The Rio Itapicuru greenstone belt, Bahia, Brazil: a probable early Proterozoic subduction-related magmatic arc. Precambrian Research $42,1-17$.

Gaal, G., Teixera, J.B.G., D’el-Rey Silva, L.J.H., Silva, M.G., 1987. Early Proterozoic crustal evolution and metallogenesis, northwestern Bahia, Brazil. International Symposium on granites and metallogenesis. Unpublished Conference at ISGAM, Salvador.

Griffon, J.C., 1967. Apresentação do mapa geológico (1/100 000) da parte central da Serra de Jacobina (Bahia). Congresso Brasileiro de Geologia. Resumo das comunicações. Curitiba. Boletim Paranaense de Geociências 26, 33-34.

Kober, B., 1986. Whole-grain evaporation for ${ }^{207} \mathrm{~Pb} /{ }^{206} \mathrm{~Pb}$ age investigations on single zircons using a double-filament thermal ion source. Contributions to Mineralogy and Petrology 93, 482-490.

Ledru, P., Cocherie, A., Barbosa, J., Onstott, T., Johan, V., 1994. Ages du métamorphisme granulitique dans le craton de São Francisco (Brésil),
Implications sur la nature de l'orogène transamazonien. Comptes Rendus de l'Académie des Sciences, Paris 318-II, pp. 251-257.

Ledru, P., Milési, J.P., Johan, V., Sabaté, P., Maluski, H., 1997. Foreland basins and gold-bearing conglomerates: a new model for the Jacobina basin (São Francisco province Brazil). Precambrian Research 86, $155-176$.

Leo, G.W., Cox, D.P., Carvalho, J.P.P., 1964. Geologia da parte sul da Serra de Jacobina, Bahia, Brasil. Departamento Nacional da Produção Mineral/DGM Boletim, 209, $87 \mathrm{p}$.

Loureiro, H.S.C., Santos, R.A., 1991. Estatigrafia: Folha Mundo Novo. Loureiro, H.S.C. (Org.). Mundo Novo, folha SC. 24 Y D IV: Estado da Bahia, texto explicativo. Brasilia: DNPM. (Programa Levantamentos Geológicos Básicos do Brasil). Convênio DNPM-CPRM, pp. 18-21.

Ludwig, K.R., 1999. User's manual for Isoplot/Ex, Version 2.10. A geochronological toolkit for Microsoft Excel. Berkeley Geochronology Center Special Publication No. 1a, Berkeley, CA.

Marinho, M.M., 1991. La séquence volcanosédimentaire de Contendas Mirante et la bordure occidentale du bloc de Jequié (craton du São Francisco, Brésil): un exemple de transition Archéen-Protérozoïque. Thèse de l'Université de Clermont Ferrand.

Marinho, M.M., Vidal, P., Alibert, C., Barbosa, J.S.F., Sabaté, P., 1994. Geochronology of the Jequié-Itabuna granulitic belt and of the Contendas-Mirante volcano-sedimentary belt. Boletim de Instituto de Geociências, Universidade de São Paulo, Publicação especial 17, 73-96.

Martin, H., Sabaté, P., Peucat, J.J., Cunha, J.C., 1991. Un segment de croûte continentale d'âge archéen ancien (3.4 milliards d'années): le massif de Sete Voltas (Bahia, Brésil). Comptes Rendus de l'Académie des Sciences, Paris 313, 531-538.

Martin, H., Peucat, J.J., Sabaté, P., Cunha, J.C., 1997. Crustal evolution of the early Archaean of South America: example of the Sete Voltas Massif, Bahia State, Brazil. Precambrian Research 82, 35-62.

Mascarenhas, J.F., 1969. Estudo geológico da parte norte da Serra de Jacobina, Bahia, Brasil. Boletim da Sociedade Brasileira de Geologia, São Paulo 18-1, 3-21.

Mascarenhas, J.F., 1976. Estruturas do tipo greenstone belt no leste de Bahia, Congresso Brasileiro de Geológia, 29. Belo Horizonte, SGB, Ouro Preto, vol. 4., pp. 25-49.

Mascarenhas, J.F., Garcia, T.W., 1989. Mapa geocronológico do Estado da Bahia. Escala 1/1000 000, texto explicativo. SGM/SME (Superinted. Geol. Recursos Minerais Secr Minas Energia), Bahia, Salvador, 190 p.

Mascarenhas, J.F., Silva, E.F.A., 1994. Greenstone belt de Mundo Novo: caracterização e implicações metalogenéticas no Craton do São Francisco. Série Arquivos Abertos, 5., pp. 1-32.

Mascarenhas, J.F., Conceiçao Filho, V.M., Griffon, J.C., 1992. Contribuição à geologia do groupo Jacobina, região Jacobina/Pindabaçu, Boletim de resumos expandidos. São Paulo, SBG, São Paulo, vol. 2., pp. 141142.

Melo, R.C., 1991. Geologia regional: análise do conhecimento adquirido pelo Projeto Gavião-Serrinha Filha Mundo Novo. Loureiro, H.S.C. (Org.). Mundo Novo, folha SC.24 Y D IV: estado da Bahia, texto explicativo. Brasilia: DNPM. (Programa Levantamentos Geológicos Básicos do Brasil). Convênio DNPM-CPRM, pp. 18-21.

Mougeot, R., 1996. Etude de la limite Archéen-Protérozoïque et des minéralisations $\mathrm{Au}, \pm \mathrm{U}$ associées. Exemples de la région de Jacobina (Etat de Bahia, Brésil) et de Carajas (Etat de Para, Brésil). Thèse de l'Université de Montpellier II, $306 \mathrm{p}$.

Mougeot, R., Respault, J.P., Ledru, P., Milesi, J.P., 1995. U-Pb geochronological constraint for the evolution of the Paleoproterozoic Jacobina auriferous basin (São Francisco province, Bahia, Brazil), EUG8-Strasbourg, Terra Nova 7, abstract supplement no 1, Strasbourg, p. 354.

Nägler, T.F., Kramers, J.D., 1998. Nd evolution of the upper mantle during the Precambrian: models, data and the uncertainty of both. Precambrian Research 91, 233-252.

Nutman, A.P., Cordani, U.G., 1993. SHRIMP U-Pb zircon geochronology 
of Archaean granitoids from the Contendas-Mirante area of the São Francisco Craton, Bahia, Brazil. Precambrian Research 63, 179-188.

Nutman, A., Cordani, U.G., Sabaté, P., 1994. SHRIMP U-Pb ages of detrital zircons from the early Proterozoic Contendas-Mirante supracrustal belt, São Francisco craton, Bahia, Brazil. Journal of South American Earth Sciences 7 (2), 109-114.

Paces, J.B., Miller, J.D., 1993. Precise U-Pb ages of Duluth Complex and related mafic intrusions, northeastern Minnesota: Geochronological insights to physical, petrogenetic, paleomagnetic, and tectonomagmatic process associated with the $1.1 \mathrm{Ga}$ Midcontinent Rift System. Journal of Geophysical Research 38, 13,997-14,013.

Peixoto, W.P., Froés, R.J.B., Bastos Leal, L.R., 1996. Geologia e potencial metalogenético do Greenstone Belt de Riacho de Santana, Congresso Brasileiro de Geologia. 39 Anais, Salvador, vol. 1., pp. 109-112.

Peucat, J.J., Ménot, R.P., Monnier, O., Fanning, M.C., 1999. The Terre Adélie basement in the East-Antarctica shield: geological and isotopic evidence for a major $1.7 \mathrm{Ga}$ thermal event; comparison with the Gawler Craton in South Australia. Precambrian Research 94, 205-224.

Pupin, J.P., 1980. Zircon and granite petrology. Contribution for Mineralogy and Petrology 73, 207-220.

Roig, H.L., Moya, M.M., Aron, P., 1992. Ocorrências de ouro na região de Pindobaçu, Bahia, Congresso Brasileiro de Geologia, Boletim de resumos expandidos, SBG, São Paulo, vol. 1., pp. 235-236.

Sabaté, P., 1996. Estrutura e tectônica do embasamento Arqueano/ Proterozóico Inferior do Estado da Bahia. In: Barbosa, J.S.F., Domingues, J.M.L. (Eds.), Mapa Geológico do Estado da Bahia, Texto Explicativo, Escala 1/1,000,000, Governo do Estado da Bahia/ Universidade Federal da Bahia, Salvador, pp. 199-226.

Sabaté, P., Marinho, M.M., Vidal, P., Caen Vachette, M., 1990. The 2 Ga peraluminous magmatism of the Jacobina-Contendas Mirante belts (Bahia, Brazil): geologic and isotopic constraints on the sources. Chemical Geology 83, 325-338.

Sabaté, P., Barbosa, J.S.F., Marinho, M.M., 1994a. The São Francisco craton: a short outline. Boletim de Instituto de Geociências, Universidade de São Paulo, Publicação especial 17, 2-8.

Sabaté, P., Peucat, J.J., Melo, R.C., Pereira, L.H.M., 1994b. Datação por Pb evaporação de monozircão em ortognaisses do Complexo Caraíba. Expressão do Acrescimento Crustal Transamazônico do cinturão Salvador-Curaçá (Craton do São Francisco, Bahia, Brasil), Congresso
Brasileiro de Geologia, 38. Belo Horizonte, Resumos Expandidos, SBG, vol. 1., pp. 219-220.

Sampaio, A.R., 1992. Gavião, folha SC. 24-Y-D-II; Estado da Bahia Brasília: DNPM, 1992 (programa Levantamentos Geológicos Básicos do Brasil). Convênio DNPM/CPRM.

Santos Pinto, M., Peucat, J.J., Martin, H., Sabaté, P., 1998. Recycling of the Archean crust: the case study of the Gavião, state of Bahia, NE Brazil. Journal of South American Earth Sciences 11 (5), 487-498.

Silva, M.G., 1992. Evidências isotópicas e geocronológicas de um fenômeno de acrescimento crustal transamazônico no Craton do São Francisco, Estado da Bahia, Congresso Brasileiro de Geologia, 37, Resumos SBG, São Paulo, vol. 2., pp. 181-182.

Souza, S.L., Mascarenhas, J.F., Moraes, A.M.V., 1996. Geológia do greenstone belt de Mundo Novo, Bahia, Congresso Brasileiro de Geológia, 39, SBG, Salvador, Anais, vol. 1., pp. 103-106.

Stacey, J.S., Kramer, J.D., 1975. Approximation of terrestrial lead isotopic evolution by a two stage model. Earth and Planetary Science Letters 26, 207-221.

Steiger, R.H., Jäger, E., 1977. Subcommission on geochronology: convention to use of constants in geo and cosmology. Earth and Planetary Science Letters 36, 359-362.

Teixeira, W., Sabaté, P., Barbosa, J.S.F., Noce, C.M., Carneiro, M.A., 2000. Archean and Paleoproterozoic tectonic evolution of the São Francisco craton, Brazil. In: Cordani, U.G., Milani, E.J., Thomas Filho, A., Campos, D.A. (Eds.), Tectonic evolution of the South America, International Geological Congres, vol. 31., pp. 101-137, Rio de Janeiro, Brazil.

Williams, I.S., 1998. U-Th-Pb geochronology by ion microprobe. In: McKibben, M.A., Shanks, W.C. III, Ridley, W.I. (Eds.), Applications of Microanalytical Techniques to Understanding Mineralizing Processes, Reviews in Economic Geology, 7., pp. 1-35.

Wilson, N., 1987. Combined $\mathrm{Sm}-\mathrm{Nd}, \mathrm{Pb}-\mathrm{Pb}$ and $\mathrm{Rb}-\mathrm{Sr}$ geochronology and isotope geochemistry in polymetamorphic Precambrian terrains/ examples from Bahia, Brazil and Channel Island. UK Master Thesis. University of Oxford.

Wilson, N., Moorbath, S., Taylor, P.N., Barbosa, J.S.F., 1988. Archean and early Proterozoic crustal evolution in the São Francisco craton, Bahia, Brazil. Chemical Geology 70 (1-2), 146. 